\title{
The Black Sea Trout, Salmo labrax Pallas, 1814 (Pisces: Salmonidae) in Romanian Waters
}

\author{
Călin LAȚIU ${ }^{1}$, Daniel COCAN ${ }^{1}$, Paul UIUIU ${ }^{1}$, Andrada IHUȚ ${ }^{1}$, \\ Sabin-Alexandru NICULA ${ }^{2,3}$, Radu CONSTANTINESCU ${ }^{1}$, Vioara MIREȘAN ${ }^{1 *}$ \\ ${ }^{1}$ University of Agricultural Sciences and Veterinary Medicine Cluj-Napoca, Cluj County, Romania, \\ Mănăștur Street 3-5, 400372, Faculty of Animal Science and Biotechnologies, Department I Fundamental \\ Sciences (Romania) \\ ${ }^{2}$ Centre for Research on Settlements and Urbanism, Faculty of Geography, "Babeş-Bolyai" University, Cluj- \\ Napoca, 5-7 Clinicilor St., RO-400006, (Romania) \\ ${ }^{3}$ National Institute for Economic Research "Costin C. Kiriţescu", Romanian Academy, Bucharest, Casa \\ Academiei Române, 13 Septembrie St., no. 13, R0-05071 (Romania) \\ *corresponding author: vioara.mireșan@usamvcluj.ro
}

Bulletin UASVM Animal Science and Biotechnologies $77(2) / 2020$

ISSN-L 1843-5262; Print ISSN 1843-5262; Electronic ISSN 1843-536X

DOI:10.15835/buasvmcn-asb: 2020.0017

\begin{abstract}
The review assembles chronological data on Black Sea trout (Salmo labrax) from Romanian waters and brings up-to-date information related to the distribution of the species. The information used dates from 1909 to 2020 and includes books, articles, digital databases, field observations, and notes from different research fields such as ichthyology, biogeography, genetics, aquaculture, conservation, and ecology. Global distribution, migration, meristic characters, and aquaculture of the species were analyzed based on the recorded data from the specialty literature. New information related to a possible population of Salmo labrax inside the Carpathian Arch was discussed. In Romanian waters the species is found in the Black Sea, Danube, Danube Delta but the current paper proposes a new hypothesis, namely that resident populations can be found in rivers and lakes adjacent to the Carpathian Arch. The highest migration point of the Black Sea trout in the Danube was recorded near Corabia locality, Olt County, $\left(43^{\circ} 46^{\prime} 25^{\prime \prime} \mathrm{N}-24^{\circ} 30^{\prime} 12^{\prime \prime} \mathrm{E}\right)$. In the Danube Delta, it was caught in all the three branches (Sulina, Sf. Gheorghe and Chilia), and lagoonary complexes such as Razim-Sinoe. Sexually matured females were caught especially in Spring Season while unmatured specimens were caught in all seasons. Even if the species is protected under Romanian legislation, fishermen and anglers should report its presence when caught accidentally.
\end{abstract}

Keywords: Salmonidae, ichthyology, rare species, Salmo genus, Black Sea.

\section{Introduction}

Worldwide, fish species which belong to the Salmonidae family are grouped in three subfamilies (Coregoninae, Salmoninae, and Thymallinae), and eleven genera: Prosopium, Stenodus, Salvethymus, Btachymystax, Parahucho, Hucho, Salmo, Salvelinus, Coregonus, Oncorhynchus, Thymallus (Eschmeyer's Catalogue of Fishes, 2020). The last six genera are also found in Europe (Kottelat \& Freyhof, 2007).
Fishes from the Salmonidae family have economic (food source), environmental (diversity, aquatic ecosystem health) and social (angling) importance (Davidson et al., 2010). In Romania are present all the genera assigned to Europe with the following species: Danube salmon (Hucho hucho); brown trout (Salmo trutta), Black Sea salmon (Salmo labrax), brook trout (Salvelinus fontinalis), arctic charr (Salvelinus alpinus), European whitefish 
(Coregonus lavaretus), European cisco (Coregonus albula), rainbow trout (Oncorhynchus mykiss) and European grayling (Thymallus thymallus) (Bănărescu, 1964; Cocan \& Mireșan, 2018). The distribution and taxonomy of salmonids in Europe and in Romanian waters is unclear and requires increased attention (Kottelat and Freyhof, 2007; Ihut et al., 2014). One of the less frequent and studied salmonid fish species is the Black Sea salmon or the Black Sea trout (Salmo labrax) (Muhareem et al., 2011). The species was first described by Peter Simon Pallas in 1831. Since then, the Black Sea trout was considered a subspecies of Salmo trutta (subspecies name: Salmo trutta labrax) by Berg, (1948); Bănărescu, (1964); Svetovidov (1984); Lelek, (1987), synonym to Salmo trutta by Kalayci et al., (2018) and as a stand-alone species by Kottelat, (1997); Turan et al., (2014). The valid name of the species is Salmo labrax Pallas 1814. The Black Sea trout population is decreasing according to Bănăduc et al., (2016). It is an anadromous species and its presence is threatened by damming and ecosystem stress caused by landscape degradation and conversion (Kalayci et al., 2018). Genetic studies show differences among Salmo species from the Black Sea and Danube lineage, Adriatic Sea, and Altlantic lineages (Pustovrh et al., 2014). Interspecific hybridization is possible (Salmo trutta vs. Salmo labrax) and studies show that purebred specimens preserve coloration patterns similar to their parents (Kalayci et al., 2018). The aim of this paper was to assemble the existing data from the speciality literature and to add new information that may improve the knowledge related to the Black Sea trout.

\section{Materials and methods}

In this paper, books, articles, recreational fishing (angling) materials, and field observations were analyzed to gather information related to Salmo labrax in Romanian waters. Specialty literature and field observations were used to complement data and information on the species. Chronological data analysis was drafted to facilitate a better understanding of the Black Sea trout distribution and also how information related to this species was previously presented. Biology, ecology, conservation status, and description of the species were compiled based on the specialty literature. Field observations of ichthyofauna monitoring from Someșul Cald River and Beliș-Fântânele Reservoir (N 46 38.825'- E $022^{\circ}$ 51.842', Cluj County, Romania) were also added, where Salmo sp. specimens were found. We strongly believe they belong to Salmo labrax species. The specimens were captured using single-pass electrofishing techniques (using SAMUS 725G apparatus, powered by $12 \mathrm{~V}$ and 24A rechargeable battery) and fly fishing (using artificial nymphs), from July 2018 to August 2019 (Copp, 1989; Ellender et al., 2011).

\section{Results and discussion}

The presence of the species in the Black Sea and rivers that flow into the Black Sea was mentioned by many authors (Bușniță \& Alexandrescu, 1963; Bănărescu, 1964; Bănărescu, 2005), but data regarding the migration and spawning period and biology of this species is deficient (Oțel, 2007). The presence of the species could not be found when studying the existing literature.

\section{Global distribution of the Black Sea trout}

Salmo labrax

The species is distributed along the coasts of the Black and Azov Seas, and also in the rivers emptying into the seas (Bănărescu, 1964; Oțel, 2007). In general, it is referred to as an anadromous species, but there are also isolated potamodromous populations. According to IUCN Redlist, Salmo labrax is extant (resident) in Turkey, Georgia, Russia, Ukraine, Moldavia, Belarus, Romania, Bulgaria, Slovakia, Hungary, Serbia, Bosnia and Herzegovina, Czech Republic, Croatia, Montenegro, Macedonia, Poland, Austria, and Slovenia. Since the species is endemic to the Black and Azov Seas it can be assumed that it is present only in Romania, Turkey, Georgia, Russia, Bulgaria, and Ukraine based on the analyzed literature. The species is more frequent in the rivers draining in the northern part of the Black Sea: Kuban River, Don River, Dniester River, Dnieper River (Vasilieva, 2003)

\section{The migration of Salmo labrax}

Fish migration is a complex process that occurs under specific conditions and circumstances: spawning, food availability, season, searching for a new habitat (Tsukamoto et al., 2009, Guiry et al., 2020). Fish species from the Salmonidae family are anadromous and potamodromous (Quiñones et al., 2014). The adaptation capacity of fish to migrate or to reach new habitats is still an unclear subject. 
The Black Sea trout (Salmo labrax) is usually migrating for reproduction, food, new habitat, or because of hydrographic conditions (Jonsson Bror \& Nina Jonsson, 2011). Post-spawning migration is possible and also sub-adult specimens migrate from marine to freshwater (Oțel, 2007). The anadromous ecotype of Salmo labrax is found in the Black Sea coastal waters (Labón-Cerviá, 2018) while the potamodromous ecotype (river resident and lake resident) (Ferguson et al., 2019) is found in lakes and rivers from mountain areas. It is possible that in Europe, the population of Black Sea trout is decreasing because the adults are unable to reach the spawning sites represented by rivers draining into the Black Sea, because of damming, ballast exploitation and riverbed substrate alteration. According to Aurelian Popescu-Gorj and Magdalena Dimitriu (1956), the migration of Salmo labrax in the lower Danube is annual and lasts for 2 to 4 months and is stretching for long distances (around $700 \mathrm{~km}$ ). In some cases, it is also found in the floodplain lakes of the Danube.

\section{Diagnosis}

This species raised interest for ichthyologists for many years. It was considered a subspecies of Salmo trutta (Cărăușu, 1952; Bănărescu, 1964; Svetovidov, 1984) by some authors and a different species by others (Holcík, 2003; Vasilieva, 2003; Oțel, 2007; Kottelat \& Freyhof, 2007). It has anadromous and potamodromous forms (Cărăușu, 1952; Svetovidov, 1984; Vasilieva, 2003; Kottelat \& Freyhof, 2007). The coloration of the Black Sea trout Salmo labrax is silverier, the number of red spots from the body is reduced (sometimes missing) and the black spots have an $\mathrm{X}$ shape compared to those of brown trout Salmo trutta (Bănărescu, 1964) which are round. The caudal fin is slightly emarginated and has a darker posterior margin. The adipose fin is less developed than the other trout species (Popescu-Gorj \& Dimitriu, 1956; Oțel, 2007). The dentition of Salmo labrax is similar to that of Salmo trutta (both species have teeth on the upper jaw, lower jaw, tongue and vomer bone), but when compared to other species from the Salmonidae family, like Salvelinus alpinus and Hucho hucho the main difference is that the vomer dentition is missing (Constantinescu et al., 2015; Ihut etal., 2017). The number of pyloric caeca is between 40 and 62, usually 46 to 47 (PopescuGorj \& Dimitriu, 1956). In terms of habitat, the Black Sea trout is found along the coastline at depths around 50m (anadromous form). Resident forms prefer fast-flowing and cold waters with gravel and stone substrate (Kottelat \& Freyhof, 2007). According to some authors the spawning period is during Spring Season (Cărăușu, 1952; Bușniță \& Alexandrescu, 1963; Bănărescu, 1964) while other authors state that spawning occurs in the Autumn-Winter Seasons. Males can attain sexual maturity at age 1+ while females mature at 2+ (Makhrov et. al., 2018). Large specimens (larger than $2 \mathrm{~kg}$ ) caught accidentally by local fishermen in the Danube and the Danube Delta (DDBR-Danube Delta Biosphere Reserve) during the Spring Season have well developed gonads in some cases. Small specimens feed on aquatic and terrestrial invertebrates, while adults feed on invertebrates and fish (Popescu-Gorj and Dimitriu, 1956; Bănărescu, 1964; Kottelat and Freyhof, 2007). Specimens caught near Sacalin Island had Gobiidae fish species inside their digestive tract while other specimens caught in the Black Sea feed on Clupeidae species (Popecu-Gorj \& Dimitriu, 1956; Bănărescu, 1964; Oțel, 2007).

Since this species was and in some cases is still considered a subspecies of Salmo trutta, in Table 1 are presented the meristic characters for both species to highlight the main differences and the overlapping meristic characters and counts. The Black Sea trout Salmo labrax can be distinguished from the brown trout Salmo trutta by meristic characters. The dorsal fin (D) ray counts of Salmo labrax shows that the number of unbranched rays is sometimes overlapping with Salmo trutta's (S. trutta $=$ III-V vs. S. labrax = III-IV), and a fifth unbranched ray in the dorsal fin may indicate Salmo trutta. A similar result can be noticed for the branched rays (S. trutta $=9-10(11)$ vs. S. labrax =9-10). Eleven branched rays of the dorsal fin may indicate Salmo trutta. The Anal fin (A) unbranched rays number of Salmo labrax overlap to Salmo trutta $(S$. trutta $=$ II-IV vs. $S$. labrax = III-IV). The branched rays of the anal fin are sometimes larger in the case of Salmo labrax (S. trutta $=8-9$ vs. $S$. labrax $=8(10)$, but in some specimens the number of branched rays is reaching 10 . Ventral fin (V) unbranched ray count is equal for both species, meaning a full overlapping for this meristic character. The branched rays of the ventral fin of Salmo labrax are always equal to 8 , while in the case of Salmo trutta the number ranges from 7 to 9. The unbranched rays of the pectoral fin (P) 
overlap for both species. The branched ray count of the pectoral fin is overlapping if the count is 12. Eleven branched rays indicate Salmo labrax, while 13 or 14 indicate Salmo trutta. The scale count on the lateral line (LL) of Salmo labrax is between 112 and 135, while in the case of Salmo trutta is between 110 and 132. The number of scales above the lateral line (Sc A) can be used as an important meristic character for Salmo labrax diagnosis versus Salmo trutta (S. trutta $=25-26$ vs. $S$. labrax $=25-31$ ). The number of scales below the lateral line (Sc B) is usually larger in the case of Salmo labrax (S. trutta $=20-23$ vs. S. labrax $=$ 22-30). Another meristic character that may help distinguish the two species is the number of scales from the dorsal fin to the lateral line (D/LL), $(S$. trutta $=12-17$ vs. $S$. labrax $=16-23)$. The most important and eloquent meristic characters are the number of scales in an oblique row from the base of the adipose fin to the lateral line (Ad/LL) (S. trutta $=15-17$ vs. $S$. labrax $=18-19)$ and the number of gill rakers (GR) (S. trutta $=13-16$ vs. $S$. labrax $=16-21)$. The number of vertebrae (Ver) is similar (S. trutta $=56-61$ vs. . labrax $=57-60)$. The branchiostegal rays (Brs R) show similar counts but in some cases, Salmo labrax has two more rays (S. trutta $=10$ vs. S. labrax =10-12) (Table 1).

\section{Aquaculture}

The Black Sea trout Salmo labrax is not among the species farmed in Romanian aquaculture, although there is potential in this regard. The species is used in aquaculture in Turkey (Eastern Black Sea Coast and streams), from classical systems to recirculating aquaculture systems (RAS) with promising results (Nikandrov \& Shindavina, 2007; Akhan et. al., 2010; Ramazan et al., 2010; Çakmak et al., 2018a; Çakmak et al., 2018b; Çakmak et al., 2019).

\section{Can Salmo labrax inhabit rivers from inside the Carpathian Mountains Arch?}

During August 2018 and July 2019 the ichthyofauna from Someșul Cald River (Figure 1) was inventoried from its springs to Tarnița Reservoir (Dam). Along with Salmo trutta, Thymallus thymallus, Squalius cephalus, Barbus carpathicus, Barbatula barbatula, Rutilus rutilus, Phoxinus phoxinus, Cobitis elongatoides, Cottus gobio, Perca fluviatilis, and Eudontomyzon danfordi, 5 specimens of Salmo sp. were caught. The length

Table 1. Meristic characters of brown trout Salmo trutta and the Black Sea trout Salmo labrax

\begin{tabular}{|c|c|c|}
\hline Common name & Brown trout & Black Sea trout \\
\hline Species name & Salmo trutta & Salmo labrax \\
\hline Dorsal fin (D) & III-V 9-10(11) ${ }^{(\mathrm{a}, \mathrm{d})}$ & $(\mathrm{III})^{(\mathrm{e})}-\mathrm{IV} 9-10^{(\mathrm{a}, \mathrm{c}, \mathrm{e}, \mathrm{h}, \mathrm{i})}$ \\
\hline Anal fin $(A)$ & II-IV (7) 8-9 (a) & III-IV $8(10)^{(a, c, e, i)}$ \\
\hline Ventral fin (V) & I 7-9 (a, d) & $I-8^{(a, c, e, h, i)}$ \\
\hline Pectoral fin $(\mathrm{P})$ & I $12-13(14)^{(c)}$ & $\mathrm{I} 11-12^{(\mathrm{e}, \mathrm{h})}$ \\
\hline Scales on lateral line (LL) & $110-132^{\text {(c) }} 118-130^{\text {(d) }}$ & $112-122^{(\mathrm{a}, \mathrm{h}, \mathrm{i})} ; 119-132^{(\mathrm{cc})} 116-135^{(\mathrm{e})}$ \\
\hline Scales above lateral line (Sc A) & $25-26^{(c)}$ & $25-31^{(c)}$ \\
\hline Scales below lateral line (Sc B) & $20-23^{(c)}$ & $22-30(c, \mathrm{e})$ \\
\hline Scales D/LL & $12-17$ (a) & $16-23^{\text {(a) }}$ \\
\hline Scales Ad/LL & $15(17)^{(d)}$ & $18(19)^{(c, d)}$ \\
\hline Vertebrae (Ver) & $56-61^{(d)}$ & $57-60^{(a, c, h)}$ \\
\hline Gill rakers (GR) & $13-18(14-16)^{(d)}$ & (16) 17-18 (19-21) ${ }^{(\mathrm{a}, \mathrm{b}, \mathrm{c}, \mathrm{d}, \mathrm{e}, \mathrm{h}, \mathrm{i})}$ \\
\hline Brachiostegal rays (Brs R) & $10^{(\mathrm{g})}$ & $10-12^{(c)}$ \\
\hline \multicolumn{3}{|c|}{$\begin{array}{l}\text { Superscripts: } a \text {-Petru Bănărescu (1964); } b \text {-Kottelat \& Freyhof (2007); } c \text {-Cărăușu (1952); } d \text {-Svetovidov (1984); } e \text {-Holč́ík \& Stefanov (2008); } \\
\text { f-Bușniță \&d Alexandrescu (1963); g-Page \& Burr (1991); } h \text {-Oțel (2007); i-Popescu-Gorj \& Dimitriu (1956) }\end{array}$} \\
\hline \multicolumn{3}{|c|}{$\begin{array}{l}\text { Legend: D-dorsal fin; A-anal fin; V-ventral fin; P-pectoral fin; LL-lateral line scales; Sc A-scales above the lateral line; Sc B-scales below th } \\
\text { lateral line; D/LL-scales from dorsal fin to the lateral line; Ad/LL-scales in oblique row from the base of the adipose fin to the lateral line } \\
\text { Ver-Vertebrae; GR-gill rakers from the first arch; Brs R-branchiostegal rays. }\end{array}$} \\
\hline
\end{tabular}




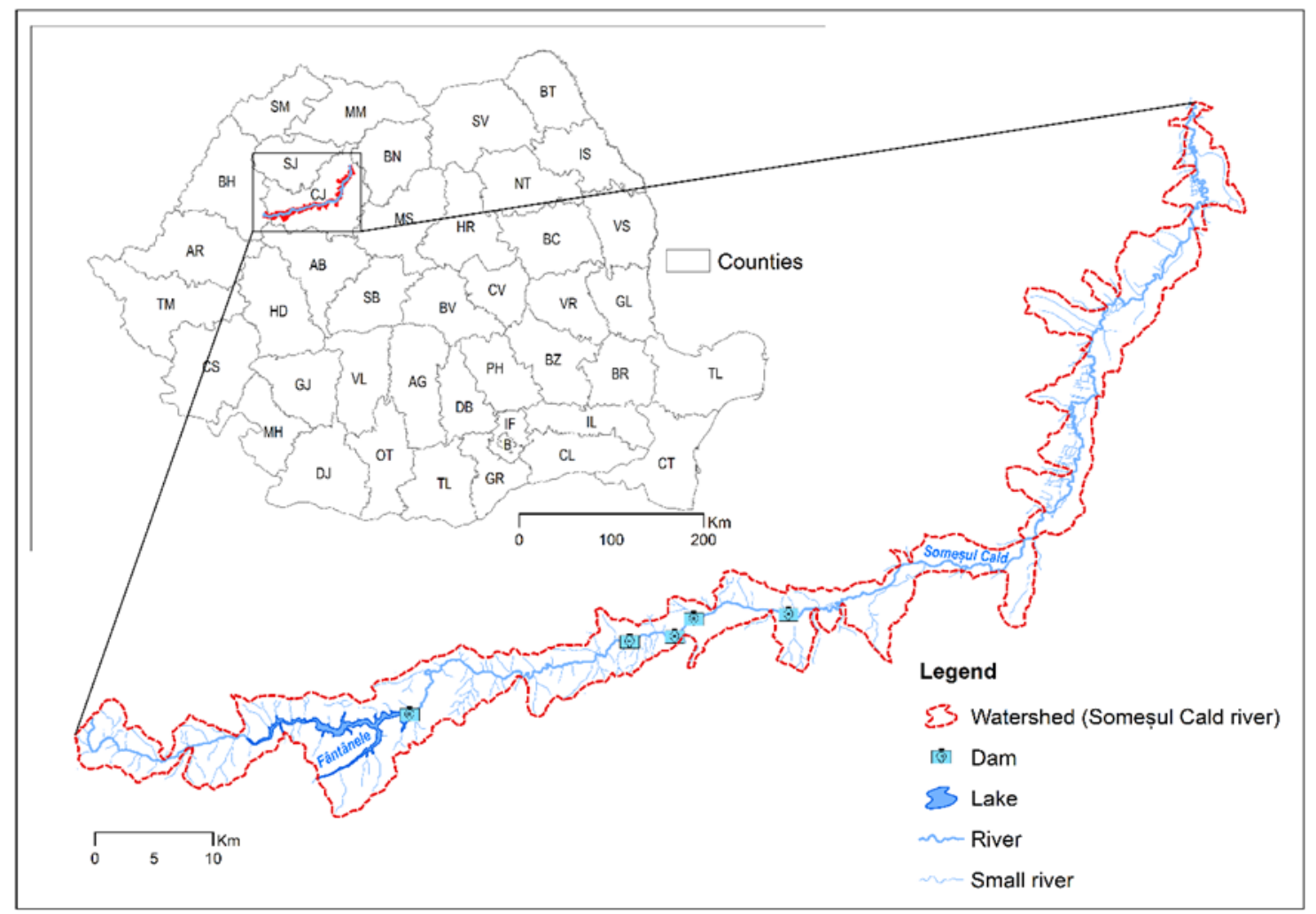

Figure 1. Someș River catchment (original map)

of specimens ranged from 19.5 to $24.4 \mathrm{~cm}$ and weighted from 55.2 to $99.9 \mathrm{~g}$.

We assumed they belong to Salmo labrax species (Figure 2-D, E) based on meristic characters such as the number of scales from the dorsal fin to the lateral line (D/LL = 19 for Figure 2.D and D/ $L L=22$ for Figure 2.E) and also based only on a few particularities: silver body, dark spots, lack of red spots, emarginated caudal fin and the darker posterior margin of the caudal fin. The specimens were photographed weighed, measured, and released. Further studies are planned to confirm the identoty of the species. The superior section of Someșul Cald River (Apuseni Mountains Natural Park) that runs through a karst area is the main water body that supplies Beliș-Fântânele Reservoir, built between 1970 and 1974. If karst geomorphology and geographical fragmentation like the construction of dams and large reservoirs influenced Salmo labrax populations, it is very likely to find other populations in similar geographic contexts, such as Drăgan River and Drăgan-Floroiu Reservoir, Sebeș River and Oașa Reservoir. In some countries, Salmo labrax habitat is located in lakes and the upper courses of the rivers running through karst relief (Marko et al., 2019). Karst structures may have a similar geographical role in some species conservation and distribution such as for the stone crayfish Austropotamobius torrentium (Pârvulescu et al., 2013). This approach could be used for Salmo labrax distribution. If the specimens caught in Someșul Cald River and BelișFântânele Reservoir belong to Salmo trutta (not Salmo labrax) or other species, the silver color and the lack of red spots could be a manifestation of plesiomorphic coloration found in Atlantic salmon Salmo salar. Stearley and Smith (1993) stated that the X shape dark spots of Salmo salar are an autapomorphy (unique trait). Clearly, Salmo labrax has dark/black X shape spots and it suggests that this character/trait is an apomorphy (a shared trait of Salmo salar and Salmo labrax).

\section{Conclusion and Recommendations}

The anadromous ecotype of Salmo labrax has been found until now on the Romanian Black Sea coast and on the branches of the Danube Delta: - Sulina Branch: Gorgova Village, Maliuc Village

- Sf. Gheorghe Branch: Sf. Gheorghe Village 


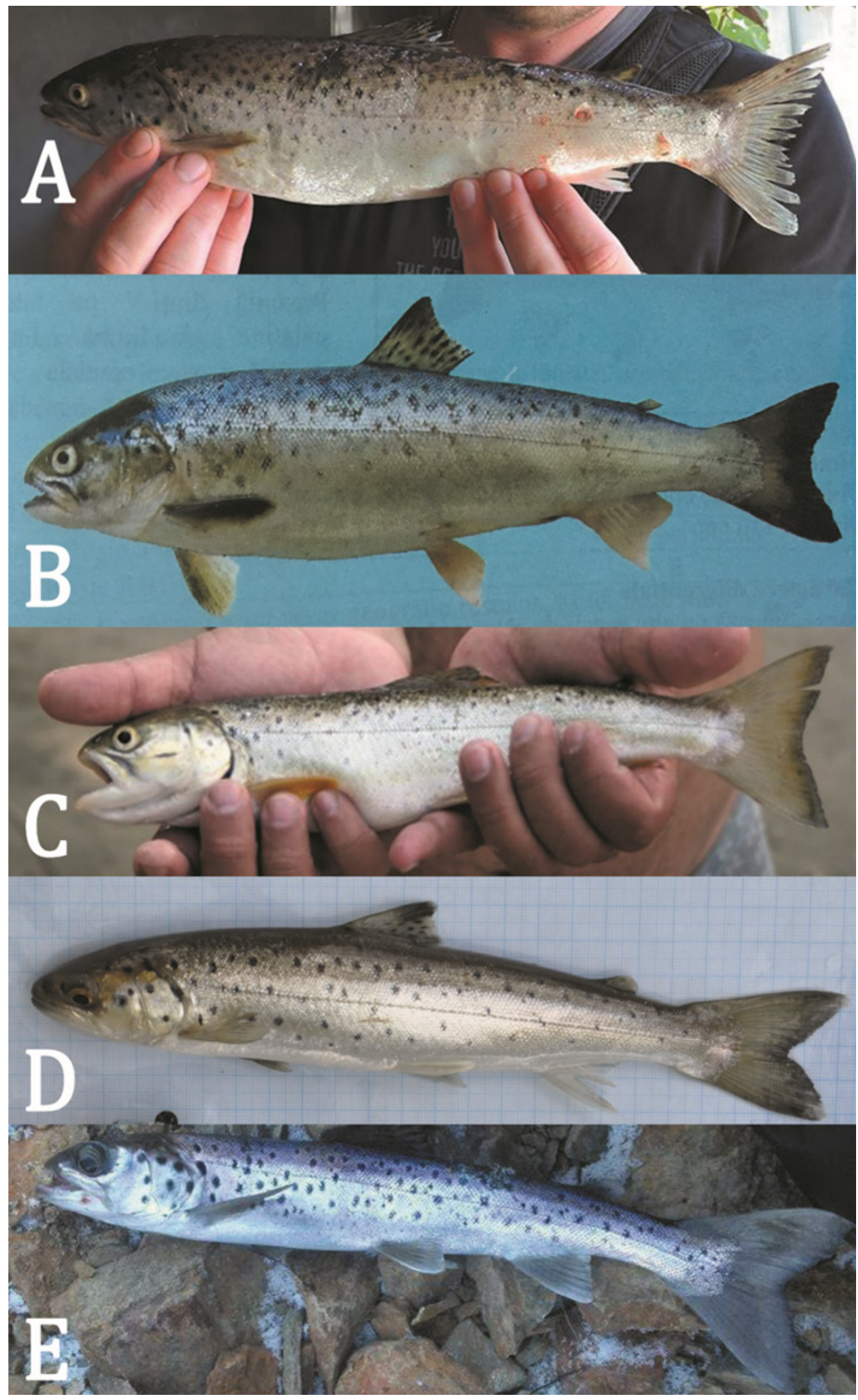

Figure 2. Salmo labrax from: A-Black Sea (photo credit: Daniel Cocan), B-Danube Delta, Sf. Gheorghe branch (photo credit: Vasile Oțel), C-Danube, Corabia (photo credit: Vasile Oțel), D-Someșul Cald River (photo credit: Călin Lațiu), E-Beliș Reservoir (photo credit: Ioan Rotar/Călin Lațiu) 
Table 2. Chronological data mentions of Salmo labrax in and near Romanian waters

\begin{tabular}{|c|c|c|c|c|c|c|}
\hline Year & Authors & Synonym used & Romanian habitat & Location & Frequency & Observations \\
\hline 1909 & Antipa Grigore & Salmo salar fario & $\mathrm{n} / \mathrm{a}$ & $\mathrm{n} / \mathrm{a}$ & $\mathrm{n} / \mathrm{a}$ & $\begin{array}{l}\text { the name probably used } \\
\text { for Salmo labrax }\end{array}$ \\
\hline 1948 & Berg L.S. & $\begin{array}{l}\text { Salmo trutta } \\
\text { labrax }\end{array}$ & $\begin{array}{c}\text { Black Sea, Danube } \\
\text { basin }\end{array}$ & $\mathrm{n} / \mathrm{a}$ & $\mathrm{n} / \mathrm{a}$ & $\mathrm{n} / \mathrm{a}$ \\
\hline 1952 & $\begin{array}{l}\text { Cărăușu } \\
\text { Sergiu }\end{array}$ & $\begin{array}{l}\text { Salmo trutta } \\
\quad \text { labrax }\end{array}$ & $\begin{array}{l}\text { Black Sea, Danube, } \\
\text { Lake Ialpug }\end{array}$ & $\begin{array}{c}\text { Black Sea coastal waters, } \\
\text { Danube and Danube } \\
\text { Delta }\end{array}$ & rare & Spawns at the end of April \\
\hline 1956 & $\begin{array}{l}\text { Popescu-Gorj } \\
\text { Aurelian } \\
\text { and Dimitriu } \\
\text { Magdalena }\end{array}$ & $\begin{array}{l}\text { Salmo trutta } \\
\text { labrax }\end{array}$ & $\begin{array}{l}\text { Black Sea, Danube, } \\
\text { Danube Delta }\end{array}$ & $\begin{array}{l}\text { Flooding lakes and } \\
\text { ponds from the Danube } \\
\text { Delta, Jirlia (Călărași), } \\
\text { Măgureni, Sf. Gheorghe } \\
\text { Branch }\end{array}$ & rare & $\begin{array}{l}\text { Specimens around } 27 \mathrm{~cm} \\
\text { were } 3 \text { to } 4 \text { years old }\end{array}$ \\
\hline 1964 & $\begin{array}{l}\text { Bănărescu } \\
\text { Petru }\end{array}$ & $\begin{array}{l}\text { Salmo trutta } \\
\quad \text { labrax }\end{array}$ & $\begin{array}{l}\text { Black Sea, Danube, } \\
\text { Danube Delta }\end{array}$ & $\begin{array}{l}\text { The Black Sea, Danube } \\
\text { (upper migration point - } \\
\text { Călărași), Danube Delta, } \\
\text { Razim-Sinoe lagoon } \\
\text { complex }\end{array}$ & rare & $\mathrm{n} / \mathrm{a}$ \\
\hline 1984 & $\begin{array}{l}\text { Svetovidov, } \\
\text { A.N. }\end{array}$ & $\begin{array}{l}\text { Salmo trutta } \\
\text { labrax }\end{array}$ & Black Sea & $\mathrm{n} / \mathrm{a}$ & $\mathrm{n} / \mathrm{a}$ & $\mathrm{n} / \mathrm{a}$ \\
\hline 1987 & Lelek Anton & $\begin{array}{l}\text { Salmo trutta } \\
\text { labrax }\end{array}$ & Black Sea & $\mathrm{n} / \mathrm{a}$ & $\mathrm{n} / \mathrm{a}$ & $\begin{array}{l}\text { Specimens from the Black } \\
\text { Sea may reach } 100 \mathrm{~cm} \text { in } \\
\text { length (total length) }\end{array}$ \\
\hline 1992 & $\begin{array}{l}\text { Oțel Vasile } \\
\text { et al. }\end{array}$ & $\begin{array}{l}\text { Salmo trutta } \\
\text { labrax }\end{array}$ & Razim Lake & $\begin{array}{c}\text { Razim-Sinoe lagoon } \\
\text { complex }\end{array}$ & & $\mathrm{n} / \mathrm{a}$ \\
\hline 1997 & $\begin{array}{l}\text { Kottelat } \\
\text { Maurice }\end{array}$ & Salmo labrax & Black Sea, Danube & Black Sea, Danube & $\mathrm{n} / \mathrm{a}$ & $\mathrm{n} / \mathrm{a}$ \\
\hline 2003 & $\begin{array}{l}\text { Vasilieva } \\
\text { Ekaterina }\end{array}$ & Salmo labrax & Black Sea & $\mathrm{n} / \mathrm{a}$ & rare & $\begin{array}{c}\text { Lives in large rivers from } \\
\text { northern coast of the } \\
\text { Black Sea }\end{array}$ \\
\hline 2005 & $\begin{array}{l}\text { Bănărescu } \\
\text { Petru }\end{array}$ & $\begin{array}{l}\text { Salmo trutta } \\
\quad \text { labrax }\end{array}$ & $\begin{array}{l}\text { Black Sea, Danube, } \\
\text { Danube Delta }\end{array}$ & $\mathrm{n} / \mathrm{a}$ & rare & $\begin{array}{l}\text { It is found in the lower } \\
\text { sectors of rivers emptying } \\
\text { in the Black Sea }\end{array}$ \\
\hline 2007 & Oțel Vasile & Salmo labrax & $\begin{array}{l}\text { Black Sea, Danube, } \\
\text { Danube Delta }\end{array}$ & $\begin{array}{l}\text { The Danube, South of Sf. } \\
\text { Gheorghe Branch, Razim- } \\
\text { Sinoe Lagoon }\end{array}$ & rare & Caught in small numbers \\
\hline 2007 & $\begin{array}{l}\text { Milen Vassilev } \\
\text { et al. }\end{array}$ & Salmo labrax & Danube & Ruse-Giurgiu & rare & $\begin{array}{c}\text { Caught near Ruse town } \\
\text { (Bulgaria) }\end{array}$ \\
\hline 2007 & $\begin{array}{l}\text { Vasilieva } \\
\text { Ekaterina }\end{array}$ & $\begin{array}{l}\text { Salmo trutta } \\
\text { labrax }\end{array}$ & $\begin{array}{l}\text { Black Sea (all } \\
\text { coasts) }\end{array}$ & Black Sea & rare & $\begin{array}{c}\text { Freshwater } \\
\text { (potamodromous) are } \\
\text { more widespread than } \\
\text { saltwater (anadromous) }\end{array}$ \\
\hline 2007 & $\begin{array}{c}\text { Kottelat } \\
\text { Maurice and } \\
\text { Jörg Freyhof }\end{array}$ & Salmo labrax & Black Sea & Black Sea & & $\begin{array}{l}\text { Anadromous, lacustrine } \\
\text { and resident forms }\end{array}$ \\
\hline 2008 & $\begin{array}{l}\text { Holčík J. and } \\
\text { Stefanov T. }\end{array}$ & Salmo labrax & Danube & Bulgarian bank of Danube & rare & $\mathrm{n} / \mathrm{a}$ \\
\hline 2010 & $\begin{array}{l}\text { Dudu Andreea } \\
\text { et al. }\end{array}$ & Salmo labrax & $\begin{array}{l}\text { Black Sea, Danube, } \\
\text { Danube Delta, and } \\
\text { tributaries }\end{array}$ & Danube Delta & $\mathrm{n} / \mathrm{a}$ & $\mathrm{n} / \mathrm{a}$ \\
\hline 2011 & $\begin{array}{l}\text { Muharrem } \\
\text { Aksungur }\end{array}$ & $\begin{array}{l}\text { Salmo trutta } \\
\text { labrax }\end{array}$ & Black Sea & $\mathrm{n} / \mathrm{a}$ & rare & $\begin{array}{l}\text { the east coast of the Black } \\
\text { Sea }\end{array}$ \\
\hline 2011 & $\begin{array}{l}\text { Georgescu } \\
\text { Sergiu Emil } \\
\quad \text { et al. }\end{array}$ & $\begin{array}{l}\text { Salmo trutta } \\
\text { labrax }\end{array}$ & $\begin{array}{l}\text { Black Sea, Danube, } \\
\text { Danube Delta }\end{array}$ & $\mathrm{n} / \mathrm{a}$ & rare & $\mathrm{n} / \mathrm{a}$ \\
\hline
\end{tabular}


Table 2. Chronological data mentions of Salmo labrax in and near Romanian waters (continuation)

\begin{tabular}{|c|c|c|c|c|c|c|}
\hline 2012 & $\begin{array}{l}\text { Halasi-Kovacs } \\
\text { B. and Harka } \\
\text { Á. }\end{array}$ & Salmo labrax & $\begin{array}{l}\text { Black Sea, Danube, } \\
\text { Danube Delta }\end{array}$ & Western Black Sea & rare & $\mathrm{n} / \mathrm{a}$ \\
\hline 2015 & Cocan Daniel & Salmo labrax & Danube Delta & Sfantu Gheorghe Branch & rare & $\begin{array}{c}\text { Caught in August 2015/ } \\
\text { Unpublished data }\end{array}$ \\
\hline 2017 & $\begin{array}{l}\text { Simonović } \\
\text { et al. }\end{array}$ & Salmo labrax & Danube basin & $\mathrm{n} / \mathrm{a}$ & rare & $\mathrm{n} / \mathrm{a}$ \\
\hline 2018 & $\begin{array}{c}\text { Ninua Levan } \\
\text { et al. }\end{array}$ & Salmo labrax & Black Sea & $\begin{array}{c}\text { Northern and Western } \\
\text { Black Sea }\end{array}$ & rare & $\mathrm{n} / \mathrm{a}$ \\
\hline 2019 & Lațiu Călin & Salmo labrax & $\begin{array}{l}\text { Someșul Cald River, } \\
\text { Beliș Reservoir }\end{array}$ & $\begin{array}{l}\text { Doda Pilii, Beliș- } \\
\text { Fântânele Dam }\end{array}$ & rare & $\begin{array}{l}\text { Unpublished data/Fig } 1 \\
\text { (D,E) } \\
\text { First record of S. Labrax } \\
\text { inside the Carpathian } \\
\text { Mountains Arch }\end{array}$ \\
\hline 2019 & $\begin{array}{l}\text { Anonymous } \\
\text { fisherman }\end{array}$ & Salmo labrax & Danube Delta & Gorgova & rare & Unpublished data \\
\hline 2020 & $\begin{array}{l}\text { Dyldin Y. V. } \\
\text { et al. }\end{array}$ & Salmo labrax & $\begin{array}{l}\text { The Black Sea and } \\
\text { Danube Basin }\end{array}$ & $\mathrm{n} / \mathrm{a}$ & $\mathrm{n} / \mathrm{a}$ & $\begin{array}{c}\text { Anadromous and } \\
\text { potamodromous (rivers } \\
\text { and lakes) populations }\end{array}$ \\
\hline 2020 & Oțel Vasile & Salmo labrax & Danube Delta & Maliuc & rare & Unpublished data \\
\hline 2020 & FishBase & Salmo labrax & $\begin{array}{l}\text { Rivers draining to } \\
\text { the Black Sea }\end{array}$ & $\mathrm{n} / \mathrm{a}$ & rare & $\begin{array}{c}\text { Anadromous, lacustrine, } \\
\text { resident forms }\end{array}$ \\
\hline
\end{tabular}

Legend: n/a- information not available

- Chilia Branch: the Romanian bank of Chilia Branch

- Lagoon Complex Razim-Sinoe: stray specimens

- Danube River: Călărași town (Călărași County), Giurgiu town (Giurgiu County), Corabia town (Olt County)-the highest migration point observed in the Danube River Romanian waters. In some cases, its presence was signaled near Nedeia Village (Dolj County), according to Popescu Gorj and Dimitriu in 1956. It is expected to find sporadic/stray specimens of the anadromous ecotype in lagoonary lakes from the Danube Delta (Zmeica, Golovița, Leahova Mare).

The potamodromous ecotype of Salmo labrax could be found in Someșul Cald River catchment (Cluj County, N 46 38.825'; E 022 $51.842^{\prime}$ ), Northwestern of Romania. There is a high probability to find potamodromous populations in other "river-reservoir" systems from inside and outside the Carpathian Mountains Arch (Drăgan River and Drăgan-Floroiu Reservoir; Sebeș River and Oașa Reservoir). The presence of this species in the Danube Delta Biosphere Reserve is not related to spawning migration (Bănărescu, 1964), but rather for food or new habitat. It is accidentally caught from Spring to Autumn seasons by fishermen using gillnets designed for Alosa immaculata, or other fish species, and using seines while fishing in lagoonary complexes. The potamodromous form is caught by fly fishing anglers (dry flies, nymphs) from April to September (legal trout fishing season in Romania) in Someșul Cald River and Beliș-Fântânele Reservoir.

The Black Sea Salmon Salmo labrax has the endangered species status in Romanian legislation and also in all the countries where it is extant but special measures for habitat restoration are necessary. It is also essential to identify the habitat and spawning grounds of the species (both anadromous and potamodromous ecotypes). Brown trout stockings may have a negative impact on Black Sea trout populations in this sense, and it is recommended that special attention for the waters where the two species live in sympatry like the presented area of Someșul Cald River, where Salmo labrax could be present. An example for our recommendation could be the Salmo labrax population we assume is living in Someșul Cald River and Beliș-Fântânele Reservoir (Cluj County, Romania). Genetic studies are also required to compare the isolated populations from Transylvania to those from the Black Sea coast. The potamodromous ecotype of Salmo labrax needs 
further study regarding its reproductive migration behaviour (Pavlov et al., 2018). It is not clear yet if the species reproductive migration behavior is fluvial, fluvial-adfluvial, lacustrine-fluvial, or allacustrine. Also, the spawning period of the species is unclear. Some authors mention that Salmo labrax spawns in spring (Bănărescu, 1964; Oțel, 2007), while other authors mention that it spawns in autumn and winter (Kottelat \& Freyhof, 2007; Cakmak et al., 2018). The distribution of fish species from the Salmonidae family (including Salmo labrax) in Romanian waters is still "an uncharted ground" and needs increased attention.

We also recommend that genetic studies on fish should be accompanied by morphological and meristic data, geographic coordinates, and period of fish sampling.

Acknowledgements. The authors are grateful to Dr. Vasile Oțel for providing guidance and support for this paper.

\section{References}

1. Akhan S, Delihasan SF, Okumus I, Köse Ö, and Yandi I (2010). Inter-specific hybridization between Black Sea trout (Salmo labrax Pallas, 1814) and rainbow trout (Oncorhynchus mykiss Walbaum, 1792). Aquaculture Research, 42(11): 1632-1638. doi:10.1111/j.13652109.2010.02755.x.

2. Antipa G (1909). Fauna ihtiologică a României. Publicațiunime Fondului Vasile Adamachi, 294.

3. Bănăduc D, Rey S, Trichkova T, Lenhardt M, CurteanBănăduc A (2016). The Lower Danube River-Danube Delta-North West Black Sea: A pivotal area of major interest for the past, present and future of its fish fauna - A short review. Science of the Total Environment, 545-546: 137-151.

4. Bănărescu P (1964). Fauna Republicii Populare Romîne, Volumul XIII. Pisces - Osteichthyes (pești ganoizi și osoşi). Editura Academiei Republicii Populare Române, București.

5. Bănărescu P (2005). Cartea Roșie a vertebratelor din România. 225. București.

6. Berg LS (1948). Freshwater fishes of the U.S.S.R. and adjacent countries. volume $1,4^{\text {th }}$ edition. Israel Program for Scientific Translations Ltd, Jerusalem. (Russian version published 1948).

7. Bușniță T, Alexandrescu I (1963). Atlasul peștilor din apele R.P.R.. Editura Știintifică, Bucuresti, 78-79.

8. Çakmak E, Ekrem CÇ, Osman TÖ (2018a). The fifth culture generation of Black Sea Trout (Salmo trutta labrax): Culture characteristics, meat yield and proximate composition. Ege Journal of Fisheries and Aquatic Sciences, 35(1): 103-110.
9. Çakmak E, Ekrem CÇ, Zehra DD, Osman TÖ, Oğuzhan E, Şirin F (2019). Triploid Black Sea Trout (Salmo labrax Pallas, 1814) induced by heat shock and evaluation of triploidy with different techniques. Genetics of Aquatic Organisms, 3(1): 01-07.

10. Çakmak E, Sirin F, Duygu DZ, Parlak R (2018b). The agedependent reproductive performance of 4 th generation Black Sea trout (Salmo labrax Pallas, 1814). Turkish Journal of Fisheries and Aquatic Sciences, 19(6).

11. Cărăușu S (1952). Tratat de ichtiologie. Ed. Acad. R.P.R. $802 \mathrm{p}$.

12. Cocan D and Mireșan V (2018). Ihtiologie. Sistematica și Morfologia Peștilor, Manual didactic, Volumul I. Editura Colorama, Cluj-Napoca, ISBN 978-606-8778-68-6.

13. Constantinescu R, Mireșan V, Coșier V, Friș G, Cocan D (2015). Anatomical particularities of the dentition in some fish species from the Salmonidae family. AACL Bioflux, 8(2).

14. Copp GH (1989). Electrofishing for fish larvae and 0+ juveniles: equipment modifications for increased efficiency with short fishes. Aquaculture Research, 20(4): 453-462.

15. Davidson WS, Koop BF, Jones SJM, Iturra P, Vidal R, Maass A, Jonassen I, Lien S and Omholt SW (2010). Sequencing the genome of the Atlantic salmon (Salmo salar). Genome Biology, 11: 403.

16. Dudu A, Popa O, Georgescu SE, Dinischiotu A., Costache M (2010). Molecular analysis of Romanian salmonid species based on $16 \mathrm{~S}$ rRNA and 12S rRNA sequences. Archiva Zootechnica 13(3): 30-40.

17. Dyldin YV, Hanel L, Fricke R, Orlov AM, Romanov VI, Plesnik J, Interesova EA, Vorobiev DS, Kochetkova MO (2020). Fish diversity in freshwater and brackish water ecosystems of Russia and adjacent waters. Publications of the Seto Marine Biological Laboratory 45: 47-116.

18. Ellender BR, Becker A, Weyl OLF and Swartz ER (2011). Underwater video analysis as a non-destructive alternative to electrofishing for sampling imperilled headwater stream fishes. Aquatic Conservation: Marine and Freshwater Ecosystems, 22(1): 58-65.

19. Eschmeyer's Catalogue of Fishes, (2020) (http:// researcharchive.calacademy.org/research/ichthyology/ catalog/SpeciesByFamily.asp\#Salmonidae).

20. Ferguson A, Reed TE, Cross TF, McGinnity P, Prodöhl PA (2019). Anadromy, potamodromy and residency in brown trout Salmo trutta: the role of genes and the environment. Journal of Fish Biology, DOI: 10.1111/jfb.14005.

21. Fishbase.se (2020) https://www.fishbase.se/summary/ Salmo-labrax.html/Accessed 22.07.20.

22. Georgescu SE, Dudu A, Suciu R, Vîrban I, Ionescu O, Costache M, (2011). Evaluarea și caracterizarea genetică a salmonidelor din România, (Universitatea din București - Facultatea de Biologie), București.

23. Guiry E, Royle TCA, Matson RG, Ward H, Weir T, Waber N, Brown TJ, Hunt BPV, Price MHH, Finney BP, Kaeriyama M, Qin Y, Yang DY, Szpak P (2020). Differentiating salmonid migratory ecotypes through stable isotope analysis of 
collagen: Archaeological and ecological applications. PloS ONE 15(4):e0232180.

24. Halasi-Kovács B, Harka Á (2012). How many fish species are existing in Hungary? Zoogeographic and taxonomic review and evaluation of the Hungarian fish fauna. Pisces Hungarici, 6.

25. Holčík J (2003). Changes in the fish fauna and fisheries in the Slovak section of the Danube River: a review. Annales de Limnologie - International Journal of Limnology, 39 (3): 177-195.

26. Holčík J and Stefanov $\mathrm{T}$ (2008). Taxonomic status of salmonids in the Bulgarian stretch of the Danube River and their bionomic strategy. Journal of Applied Ichthyology, 24 (2008): 605-609.

27. Ihuț A, Cocan D, Uiuiu P, Lațiu C, Friș G, Mireșan V (2017) Particularities of Dentition in Some Rare Salmonid Species: Danube Salmon (Hucho hucho) and the Black Sea Trout (Salmo trutta labrax). ProEnvironment, 10: 22-25.

28. Ihuț A, Zitek A, Weiss S, Ratschan C, Holzer G, Kaufmann T, Cocan D, Constantinescu R, and Mireșan V (2014). Danube Salmon (Hucho hucho) in Central and South-Eastern Europe: A Review for the Development of an International Program for the Rehabilitation and Conservation of Danube Salmon Populations. Bulletin UASVM Animal Science and Biotechnologies, 71(2): 86-101.

29. IUCN Redlist at iucnredlist.org.

30. Jonsson B, Jonsson N (2011). Ecology of Atlantic Salmon and Brown Trout-Habitat as a Template for Life Histories. Springer Science+Business Media B.V., 2011.

31. Kalayci G, Ozturk RC, Capkin E, Altinok I (2018). Genetic and molecular evidence that brown trout Salmo trutta belonging to the Danubian lineage are a single biological species. Journal of Fish Biology, 93: 792-804. https://doi. org/10.1111/jfb.13777.

32. Kottelat M (1997). European Freshwater species, a heuristic checklist of the freshwater fishes of Europe (exclusive of former URSS) with an introduction for non-systematists and comments on nomenclature and conservation. Biologia, Bratislava, 52/supplement, 5: $1-271$.

33. Kottelat M and Freyhof J (2007). Handbook of European Freswater Species. Publications Kottelat, Swizerland.

34. Labón-Cerviá J, (2018). Brown Trout: Biology, Ecology and Management, John Wiley \& Sons Ltd.

35. Lelek A (1987). The Fresh Water Fishes of Europe, Vol. 9, Threatened Fishes of Europe, Committee for the Conservation of Nature and Natural Resources. Council of Europe, ISBN 3-89104-048-2.

36. Makhrov AA, Artamonova VS, Murza IG, Pashkov AN, Ponomareva MV, Reshetnikov SI and Christoforov OL (2018). Ecological Forms of Black Sea Brown Trout (Salmo trutta labrax) in the Mzymta River as Manifestation of Ontogenetic Plasticity. Russian Journal of Developmental Biology, 49(2): 117-127.

37. Marko Ć, Zoran M, Buj I, Davor Z, Mustafić P, Duplić A, Horvatić $S$ (2019). A review of extant croatian freshwater fish and lampreys Annotated list and distribution. Croatian Journal of Fisheries, 77: 137-234.
38. Milen V, Trichkova, T, (2007). Salmo labrax PALLAS, 1811 (Pisces: Salmonidae) - A New Record for the Bulgarian Sector of the Danube River. Acta Zoologica Bulgarica, 59(1): 97-99.

39. Muharrem A, Zengin, M, Tabak İ, Nilgün AR, Alkan A (2011). Migration, Characteristics of the Black Sea Trout (Salmo trutta labrax, Pallas, 1814) in the Eastern Black Sea Coasts and Streams. Turkish Journal of Fisheries and Aquatic Sciences, 11: 623-630.

40. Nikandrov VY and Shindavina NI (2007). Characteristics of the Hatchery-Reared Black Sea Salmon Salmo trutta labrax, ISSN 0032-9452. Journal of Ichthyology, 47(2): 184-193.

41. Ninua L, Tarkhnishvili D, Gvazava E (2018). Phylogeography and taxonomic status of trout and salmon from the Ponto-Caspian drainages, with interferences on European Brown Trout evolution and taxonomy. Ecology and Evolution, 8(5): 2645-2658.

42. Oțel V (2007). Atlasul peștilor din Rezervația Biosferei Delta Dunării, Editura Centrul de informare tehnologică Delta Dunării, Tulcea.

43. Oțel V, Bănărescu P, Nalbant T, Bacalu P, Cociaș Ș (1992). Investigații asupra ihtiofaunei dulcicole a Deltei Dunării - Rezervația Biosferei în 1991 (Investigation on the fresh water ichthyophauna in the Danube Delta - Biosphere Reserve area in 1991). Analele Științifice ale Institutului Delta Dunării, 141-152.

44. Page LM and Burr BM (1991). A field guide to freshwater fishes of North America north of Mexico. Houghton Mifflin Company, Boston.

45. Pallas PS (1814). Zoographia Rosso-Asiatica, sistens omnium animalium in extenso Imperio Rossico et adjacentibus maribus observatorum recensionem, domicilia, mores et descriptiones anatomen atque icones plurimorum. Academia Scientiarum, Petropolis, Sankt Petersburg, 3.

46. Pavlov DS, Veselov AE, Kostin VV, Efremov DA, Ruchiev MA and Tuniev SB (2018). Current State of Conditions for Reproduction of the Black Sea Trout Salmo trutta labrax in the Mzymta River. Journal of Ichthyology, 58(1): 93-103.

47. Pârvulescu L, Zaharia C, Satmari A, Drăguț L (2013). Is the distribution pattern of the stone crayfish in the Carpathians related to karstic refugia from Pleistocene glaciations?. Freshwater Science, 32(4): 1410-1419.

48. Popescu-Gorj A, Dimitriu M (1956). Somonul Mării Negre (Salmo trutta labrax Pall.) Migrator în Dunăre și Bălțile luncii inundabile. Buletinul Institutului de Cercetări Piscicole, Anul XV, nr. 4, p 31-37.

49. Pustovrh G, Snoj A and Sušnik Bajec S (2014). Molecular phylogeny of Salmo of the western Balkans, based upon multiple nuclear loci. Genetics Selection Evolution, 46(7), https://doi.org/10.1186/1297-9686-46-7.

50. Quiñones RM, Grantham TE, Harvey BN, Kiernan JD, Klasson M, Wintzer AP, Moyle PB (2014). Dam removal and anadromous salmonid (Oncorhynchus spp.) conservation in California. Reviews in Fish Biology and Fisheries, DOI 10.1007/s11160-014-9359-5.

51. Ramazan S, Süleyman A, Fatma DS (2010). The Effect of Vitamin E on Black Sea trout (Salmo labrax) broodstock 
performance. Kafkas Universitesi Veteriner Fakultesi Dergisi, 16 (Suppl-B): S219-S222, DOI:10.9775/ kvfd.2009.1364.

52. Simonović P, Tošić A, Škraba DJ, Nikolića V, Piria M, Tomljanović T, Šprem N, Mrdak D, Milošević D, Bećiraj A, Dekiće R and Povž M (2017). Diversity of Brown trout Salmo cf. trutta in the River Danube Basin of Western Balkans as Assessed from the Structure of Their Mitochondrial Control Region Haplotypes, ISSN 00329452, Journal of Ichthyology, 2017, Vol. 57, No. 4, pp. 603616. (C) Pleiades Publishing, Ltd.

53. Stearley RF and Smith GR (1993). Phytogeny of the Pacific Trouts and Salmons (Oncorhynchus) and Genera of the Family Salmonidae. Transactions of the American Fisheries Society, 122: 1-33.

54. Svetovidov AN (1984). Salmonidae. p. 373-385. In P.J.P. Whitehead, M.-L. Bauchot, J.-C. Hureau, J. Nielsen and E.
Tortonese (eds.) Fishes of the north-eastern Atlantic and the Mediterranean. UNESCO, Paris. vol. 1.

55. Tsukamoto K, Miller MJ, Kotake A, Aoyama J, Uchida $\mathrm{K}$, (2009). The origin of fish migration: the random escapement hypothesis. American Fisheries Society Symposium, 69: 45-61.

56. Turan D, Doğan E, Kaya C, and Kanyılmaz M (2014). Salmo kottelati, a new species of trout from Alakır Stream, draining to the Mediterranean in southern Anatolia, Turkey (Teleostei, Salmonidae). ZooKeys, 462: 135-151.

57. Vasilieva ED (2003). Main alterations in ichthyofauna of the largest rivers of the northern coast of the Black Sea in the last 50 years: A review. Folia Zoologica 52(4): 337358.

58. Vasilieva ED (2007). Fish of the Black Sea - Key to marine, brackish water, euryhaline, and anadromous species with color illustrations collected by S. V. Bogorodsky, Vniro Publishing, Moscow. 